\title{
The Anatomical Structure of Vegetative Organs Lavandula officinalis Chaix in the Introduction of Tashkent Botanical Garden
}

\author{
Durdona K. Fakhriddinova ${ }^{1}$, Tashkhanim R. Rakhimova ${ }^{1}$, Feruza M. Dusmuratova ${ }^{2}$, \\ Guljan M. Duschanova3 ${ }^{3}$, Sodikjon H. Abdinazarov3, Ismatjon N. Samadov ${ }^{3}$ \\ ${ }^{1}$ Biological Faculty of the National University of Uzbekistan Named after M. Ulugbek, Tashkent, Uzbekistan \\ ${ }^{2}$ Department of Pharmacognosy, Tashkent Pharmaceutical Institute, Tashkent, Uzbekistan \\ ${ }^{3}$ Tashkent Botanical Garden Named after Acad. F.N. Rusanova at the Institute of Botany of the Academy of Sciences of the \\ Republic of Uzbekistan, Tashkent, Uzbekistan \\ Email: guljon.duschanova@mail.ru
}

How to cite this paper: Fakhriddinova, D.K., Rakhimova, T.R., Dusmuratova, F.M., Duschanova, G.M., Abdinazarov, S.H. and Samadov, I.N. (2020) The Anatomical Structure of Vegetative Organs Lavandula officinalis Chaix in the Introduction of Tashkent Botanical Garden. American Journal of Plant Sciences, 11, 578-588. https://doi.org/10.4236/ajps.2020.114043

Received: March 9, 2020

Accepted: April 23, 2020

Published: April 26, 2020

Copyright $\odot 2020$ by author(s) and Scientific Research Publishing Inc. This work is licensed under the Creative Commons Attribution International License (CC BY 4.0).

http://creativecommons.org/licenses/by/4.0/

(c) (i) Open Access

\begin{abstract}
The article presents the results of research carried out by light microscopy of the anatomical structure of vegetative organs (leaf, root and stem) Lavandula officinalis Chaix of the family Lamiaceae introduced into the conditions of the Tashkent Botanical Garden of the Republic of Uzbekistan. Our studies have shown that the presence or absence of trichomes can serve as an informative sign. In $L$. officinalis trichomes are simple unicellular two-terminal; three-terminal and multi-terminal. Lavender leaf hairs accumulate essential oils under the cuticle of secreting cells, the cuticle are tightly attached to the membranes of the secretory cells due to the absence of excretion products. Based on the results of a study of the morphological and anatomical features of the leaf of $L$. officinalis, it has been established that the forms of covering hairs and essential oil glands are of diagnostic value. In the epidermal, palisade and cortex parenchymal cells of the vegetative organs, yellow-orange essential (lavender) oil is noted. Identified diagnostic features that can be used in taxonomy and can be used to identify plant materials can also be used to develop indicators of authenticity in this type of raw material.
\end{abstract}

\section{Keywords}

Anatomy, Vegetative Organs, Introduction, L. officinalis, Tashkent Botanical Garden

\section{Introduction}

The genus Lavender-Lavandula L. belongs to the family Lamiaceae-Lamiaceae 
Lindl. (family Labretaceous-Labiatae Juss.). If Carl Linnaeus in the XVIII century singled out only four kinds of lavender [1], by various estimates and classifications of the twentieth century, this genus includes 25 to 39 species, and taking into account subspecies and interspecific hybrids, the total number of taxa within the genus Lavender reaches 90 [2]-[9].

In earlier literature, at different periods, Lavandula angustifolia Mill. was known as spike lavender-L. spica L.; real lavender-L. vera DC.; lavender officinalis-L. officinalis Ch.; lavender Pyrenean (synonym: English) - L. pyrenaica DC. [2] [5] [7] [8] [9] [10] [11].

Lavandula officinalis Chaix (Lavandula angustifolia Mill.) is an herbaceous plant, forever green, grayish from drooping, shrub $30-60(100) \mathrm{cm}$ high, with a strong odor. The root is rod, ligneous, branched in the upper part. The lower lignified branches are highly branched, uplifting, bearing numerous young shoots; flower-bearing shoots tetrahedral with a long upper internode. Leaves are opposite, sessile, oblong-linear, with curled edges, $2-6 \mathrm{~cm}$ long, green or gray-green from drooping. Flowers are collected in false whorls forming spike-shaped inflorescences. Corolla is two-lipped, about $1 \mathrm{~cm}$ long, usually bluish-purple, pubescent. The fruit consists of four nuts enclosed in the remaining cup. The homeland is the French and Spanish coasts of the Mediterranean Sea; naturalized throughout Europe, North Africa and North America. It grows in Russia on the Black Sea coast of the Caucasus, Crimea [12].

The use of wild populations of lavender as medicinal and aromatic plants has been known since ancient Rome. As a cultural and aromatic herb, lavender has become cultivated in the countries of the southern and south-western Europe since the end of the XVI century [6] [8] [10]. Currently Lavandula angustifolia still is widely cultivated in the world to obtain the essential oil of lavender, essential components which are linalyl acetate, linalool and geraniol [3] [5] [6] [8].

Lavender oil is used in the perfumery, cosmetic and medical industries, and is actively used in the production of perfumes, eau de toilette, shampoos, deodorants and soaps [3] [5] [13]. The content of essential oil in freshly harvested inflorescences of narrow-leaved lavender is $0.6 \%-4.0 \%$, in terms of absolutely dry inflorescences, the oil content can sometimes reach $11 \%$. The amount of esters (linalool and linalyl acetate) that determine the quality of lavender oil, calculated as linalyl acetate, is on average $35 \%$, with a range of variation from $10 \%$ to $80 \%$. The lavender oil also contains some amount of ketone terpene-camphor. Camphor content in lavender oil an average of about $0.5 \%-1.0 \%$. The higher mass fraction of this terpenoid such as, for example, in other types of lavender perfume degrades noticeably the quality of essential oil [1] [5].

Lavender oil is included in pharmacopoeias of 16 countries of the world [14]. In scientific medicine essential oil $L$. angustifolia is used for rheumatic pain and neuralgia, as well as a good antiseptic. It has also been shown experimentally endogenous and exogenous antibacterial activity even callus L. angustifolia, and biochemical analysis showed presence of the entire set of biochemically active 
substances intact plants [15]. In folk medicine, infusion of lavender flowers has sedative, tonic, antipyretic, analgesic and bile thinning means applies also for gastrointestinal illnesses, neurasthenia and palpitation [14]. Due to the increased xerophytic Lavender successfully used in ornamental gardening in the Mediterranean and Black Sea basins, including the southern regions of Russia. In addition, lavender is a good honey plant-one hectare of lavender during its flowering period gives more than $100 \mathrm{~kg}$ of white, aromatic and tasteful honey [2] [3].

All parts of the plant contain essential (lavender) oil: leaves-up to $0.4 \%$, stems-up to $0.2 \%$, a significant amount of it accumulates in inflorescences-3.5\% - 4.5\% (according to other sources, $0.8 \%-1.6 \%$ ). The main component of the oil $(30 \%-60 \%)$ is the esters of the alcohol L-linaloolai acids (acetic, butyric, valerianic and kapronova). In addition, cineol, geraniol, borneoli, etc. were found in it. The flowers also contain tannins (up to 12\%), bitterness and resins, ursolic acid, coumarin, gerniarin. Coumarin and gerniarin are distilled simultaneously with essential oil during hydrodistillation [16].

In this regard, the scientific interest is the study of the anatomical structure of vegetative organs of Lavandula officinalis, grown in the conditions of introduction.

\section{Material and Methods}

Objective: to study the anatomical structure of vegetative organs Lavandula officinalis to determine diagnostic features and localization of a biologically active substance in organs and tissues.

The objects of study are the herbaceous plant Lavandula officinalis, growing under the conditions of introduction of the Tashkent Botanical Garden of the Academy of Sciences of the Republic of Uzbekistan. The material was collected in 2018-2019 under the introduction of the Tashkent Botanical Garden at an altitude of $466 \mathrm{~m}$ above sea level of 41.344956 lat. 69.311983 long (Figure 1).
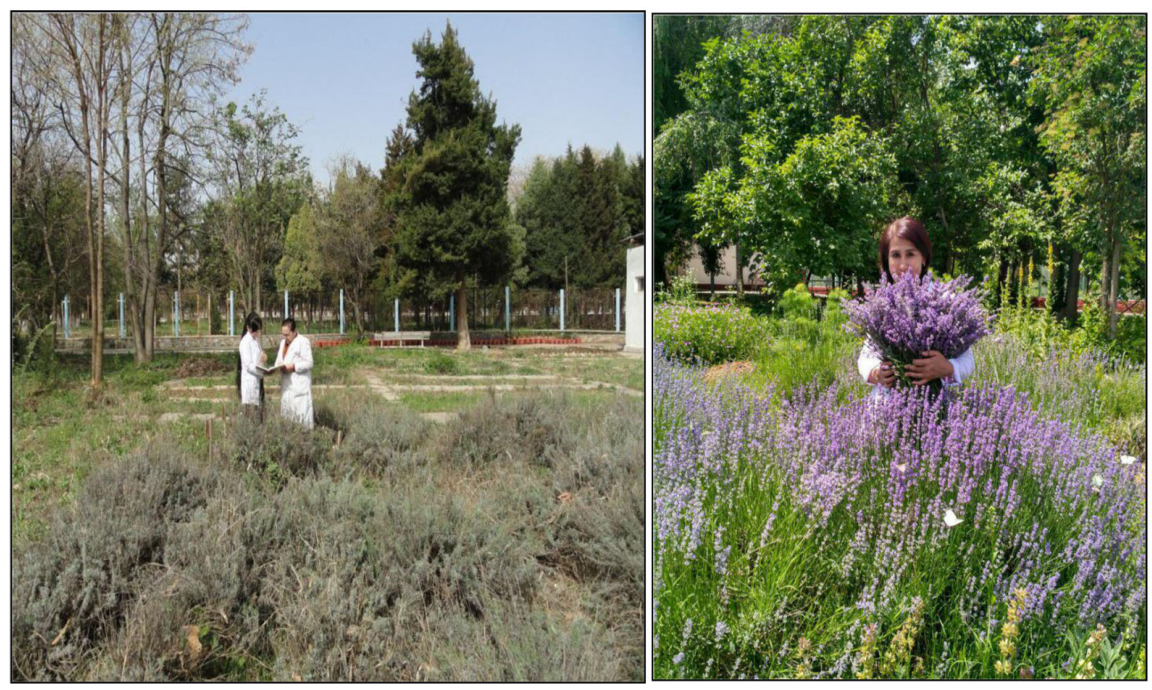

Figure 1. Appearance of Lavandula officinalis in the flowering phase. 
Lavandula officinalis has been introduced in the Tashkent Botanical Garden since 1995. Tashkent Botanical Garden is located in the north-eastern part of Tashkent in the basin; Chirchik in the low Adyr belt at an altitude of $450-480 \mathrm{~m}$ above sea level. The climate is sharply continental. The average annual rainfall during the study was $337 \mathrm{~mm}$, and the average annual temperature was $13.8^{\circ} \mathrm{C}$. Precipitation falls mainly in the autumn-winter and spring; soils of cultivated irrigated gray soils or irrigated serozems [17] [18].

Simultaneously with the morphological description, the vegetative organs (leaf, stem and root) were fixed in $70^{\circ}$ ethanol for anatomical study. A manual method was used to prepare slices of the vegetative organs. Cross sections of the leaf, stem and root were prepared manually using a safety razor. Cross sections of the leaf are made through the middle and the stem and root through the base. Sections were stained with methylene blue and safranin, followed by gluing in glycerol-gelatin [19]. Descriptions of the main tissues and cells are given according to C. Esau [20], N. S. Kiseleva [21], and the epidermis according to S. F. Zakharevich [22]. Microphotographs were taken by a computer microphoton with a Canon A123 digital camera under a Motic B1-220A-3 microscope.

\section{Result and Discussion}

\subsection{Assimilating Organs Plant}

Leaves of $L$. officinalis are opposite, sessile, oblong-linear, with curled edges, 2 $6 \mathrm{~cm}$ long, green or gray-green from pubescence. On the paradermal section, the outlines of the epidermal cells on the adaxial side are rectilinear, the projection is polygonal, the abaxial is more sinuous and the projection is polygonal. The cells of the adaxial (upper) epidermis are larger than the cells of the abaxial (lower) one. In the cell membranes of the epidermis, nucleoli are clearly visible on both sides of the leaf. Adaxial and abaxial epidermis is a pubescent with trichomes (Figure 2).

Our studies have shown that the presence or absence of trichomes can serve as an informative sign. In $L$. officinalis, trichomes are simple single cell two-pointed; three-pointed; multi-end. Lavender leaf hairs accumulate essential oils under the cuticle of secreting cells, the cuticle is tightly attached to the membranes of the secretory cells due to the lack of excretory products (Figure 2 and Figure 3).

The leaves are amphistomatic, stomata are located on both sides of the leaf blade, located transversely to the longitudinal axis of the leaf. The shape of the stomata is round-oval. The upper (adaxial) epidermis has a significantly smaller number of stomata compared to the lower (abaxial) epidermis. All this leads to a reduction in water loss from the surface of the leaf. The closing stomata cells on both sides of the leaf are almost the same length. Stomata are submerged, polocytic and diacytic types (Figure 2 and Figure 3 ).

Leaf mesophyll on the cross section of the dorsiventral type, which is represented by palisade cells located under the upper epidermis of the leaf 


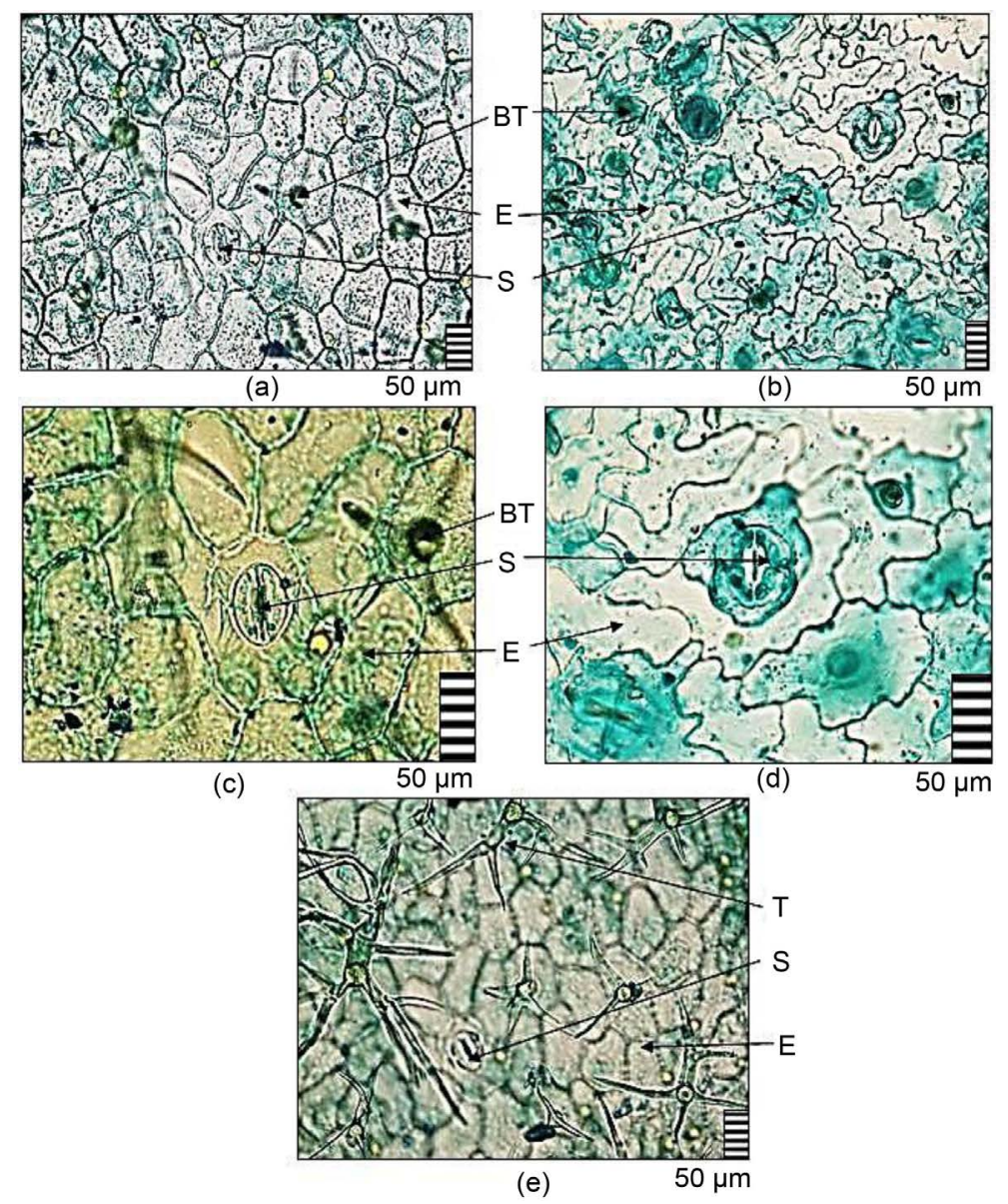

Figure 2. Anatomical structure of the epidermis of the leaf Lavandula officinalis on the paradermal section: (a), (c) upper (adaxial) epidermis; (b), (d) lower (abaxial) epidermis; (e) trichomes. Legend: BT-the basis of trichomes, E-epidermis, S-stomata. Magnification-50 - 100 micron.

mesophyll, spongy cells-above the lower epidermis of the leaf mesophyll. The epidermis is represented by one row of cells with a thick-walled cuticle layer. Adaxial epidermal cells are larger than abaxial (Figure 2).

Between the adaxial and abaxial epidermis there is an assimilation tissue consisting of palisade and spongy cells. Under the adaxial epidermis is the palisade parenchyma. The palisade parenchyma is chlorophyll-bearing, large and elongated, which consists of two rows of cells and is located between the adaxial epidermis and the spongy parenchyma of the leaf. Drops of essential oil were found in epidermal and palisade cells (Figure 3).

The spongy chlorophyll-bearing parenchyma consists of 3 - 4 rows and is located between the palisade parenchyma and the abaxial epidermis. The spongy parenchyma is round, large-cell with small cavities. Between palisade and spongy cells there are numerous lateral conducting bundles, with 3 - 4 small vessels (Figure 3).

The main leaf vein extends on the abaxial side. The rest of the vein is occupied by the main parenchyma, into which 1 conductive bundles is immersed, 


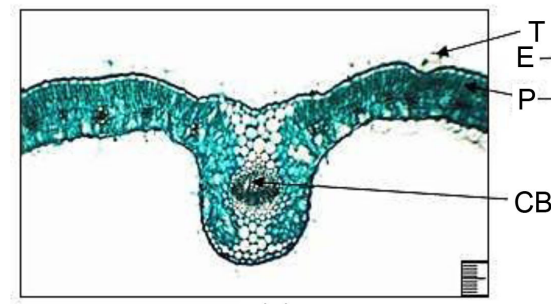

(a)

$100 \mu \mathrm{m}$

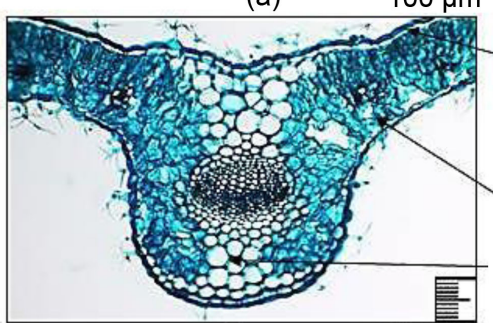

(c)

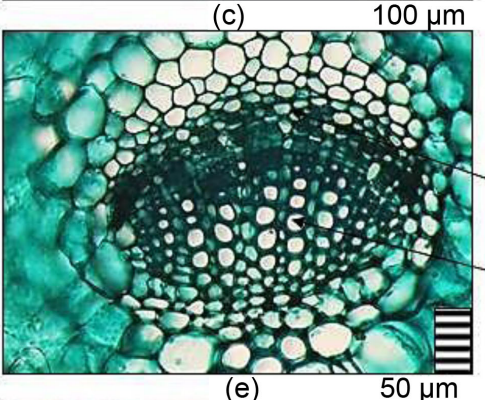

(e

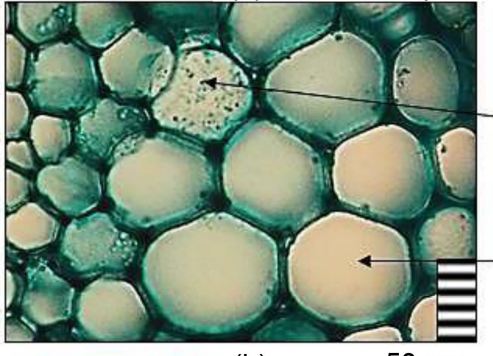

(h)

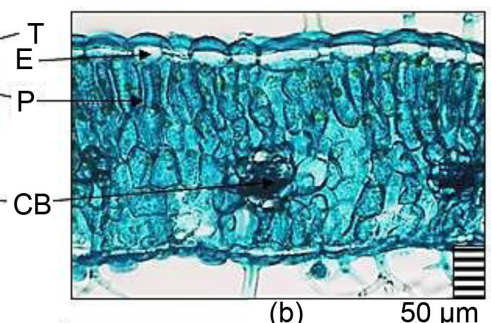

(b)

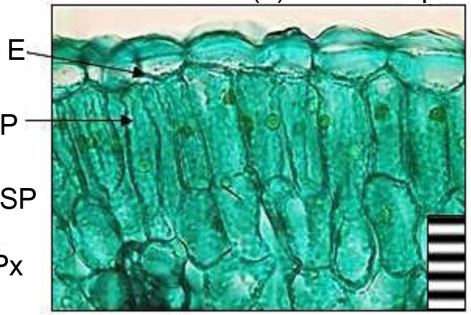

(d)

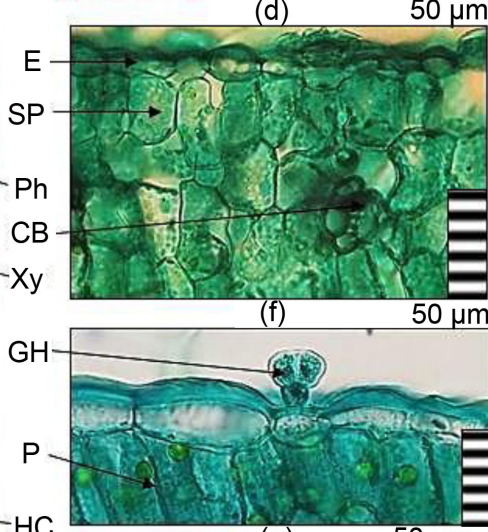

(g) $50 \mu \mathrm{m}$

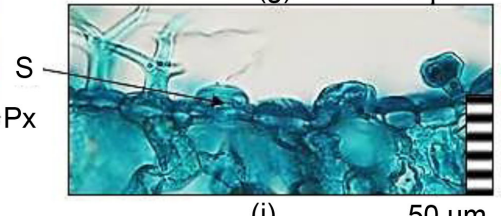

(i)

$50 \mu \mathrm{m}$

Figure 3. Anatomical structure of the leaf Lavandula officinalis on the cross section: (a) general view of the main vein of the leaf; (b) mesophyll leaf; (c) the main vein of a leaf; (d) palisade parenchyma; (e) conductive bundle; ( $f$ ) spongy parenchyma; (g) glandular hairs; (h) parenchymal and hydrocytic cells; (i) not immersed stomata. Legend: $\mathrm{CB}$-conductive bundle, E-epidermis, GH—glandular hairs, $\mathrm{HC}$-hydrocytic cells, $\mathrm{P}$-palisade parenchyma, $\mathrm{Ph}$ - phloem, $\mathrm{Px}$ - parenchyma cells, S-stomata, SP-spongy parenchyma, $\mathrm{T}$-trichomes, Xy-xylem. Magnification-50 - 100 micron.

parenchyma cells are thin-walled, round-oval, among which there are hydrocytic cells. Conductive bundles of open collateral type, numerous, consisting of phloem and xylem. Xylem is thick-walled, elongated. Their walls are thickened in the form of spirals (Figure 3).

\subsection{Axial Organs Plant}

The base of the stem on the cross section is rounded, beam type. The structures of the stems of woody plants are due to many years of active activity of the apical 
and lateral meristems. Therefore, the trunk and side branches of these plants are significantly thickened. They are powerful, highly lignified, with the early development of secondary integumentary tissue (Figure 4).

The anatomical structure of the stem is divided into three topographic zones: the periderm (cork), the secondary cortex, and the central cylinder. The integumentary tissue-the cork consists of several rows of radially located cells with thick cork-covered membranes. The integumentary tissue is represented by a cork. Its cells are dark brown in color, thick-walled, densely closed. Outwardly, upon division by tangential septa, the cells of the phellogen are formed by the cells of the tube, and inside-the cells of the phelloderm. The complex of the phellogen, phellem and phelloderm makes up the periderm. Under the periderm

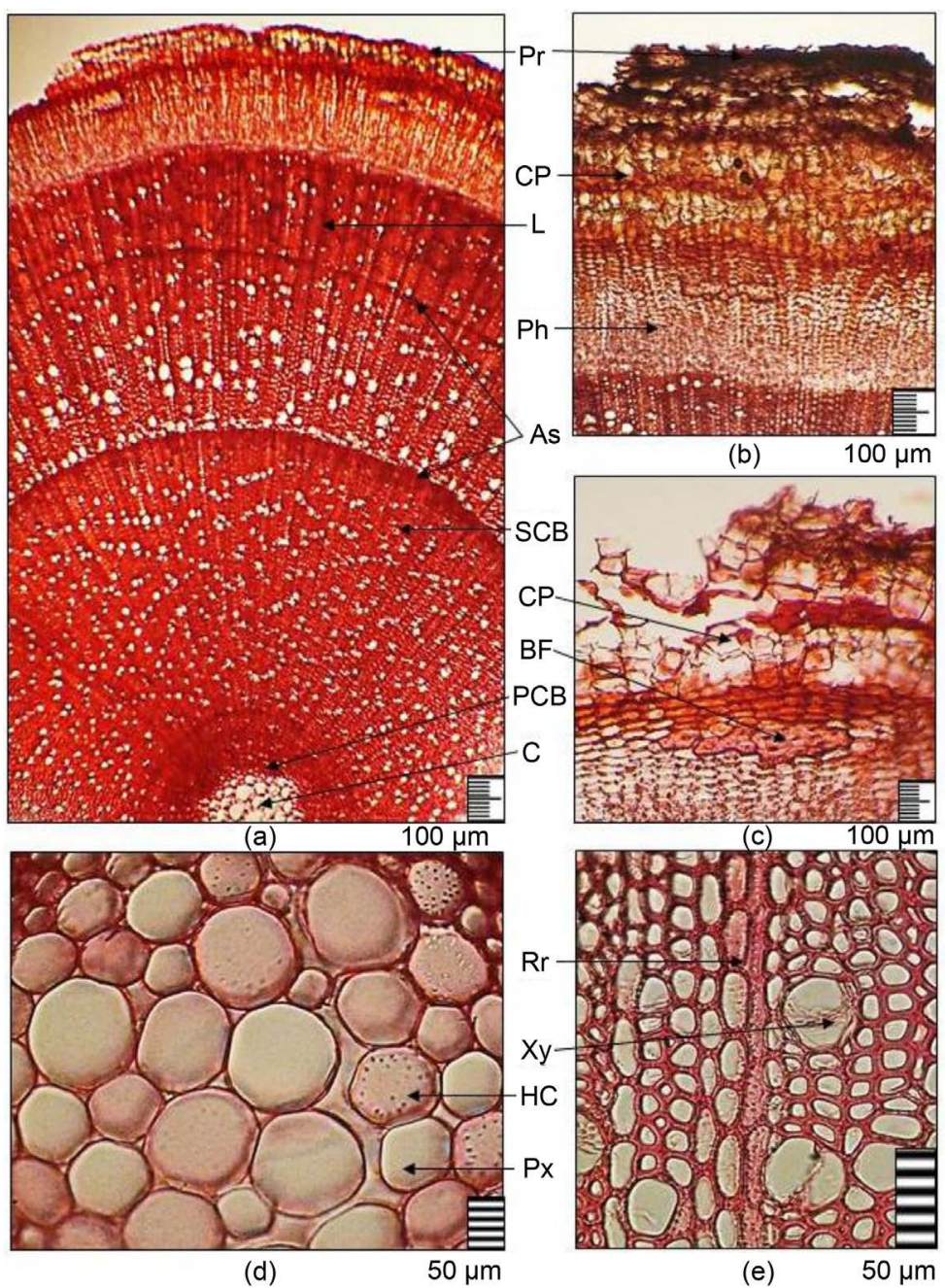

Figure 4. Anatomical structure of the stem of Lavandula officinalis on the cross section: (a) general view of the stem; (b) detail; (c) cortex parenchyma; (d) core; (e) secondary conductive bundles. Legend: As-annual shoot, $\mathrm{BF}$-bast fibers, $\mathrm{C}$-core, $\mathrm{CP}$-cortex parenchyma, $\mathrm{HC}$-hydrocytic cells, L-libriform, $\mathrm{PCB}$-primary conductive bundles, $\mathrm{Ph}-$ phloem, $\mathrm{Pr}$ - periderm, $\mathrm{Px}$ - parenchyma, $\mathrm{Rr}$ - radial rays, $\mathrm{SCB}$ - secondary conductive bundles, $\mathrm{Xy}$-xylem. Magnification-50 - 100 micron. 
is a round-oval secondary cortical parenchyma, which consists of 6 - 7 rows and remains throughout. Under the cortex parenchyma groups of bast fibers are formed. The phloem is extensive, located between the cortex parenchyma and libriform (Figure 4).

Wood occupies a continuous cylinder surrounding the core, which is located centrally in the stem. Primary conductive tissues are preserved in the stem, and then the secondary ones immediately form a continuous cylinder, which in the cross section looks like an almost continuous ring. With age, the emerging cambium changes the anatomical structure of the stem. It annually produces secondary xylem (wood). Aside xylem cambium work more vigorously, pushing the primary xylem to the core. The long and the rhythmic activity of the cambium cause a "layering" of wood. It clearly distinguishes boundary between the annual increment (the annual rings). This is due to differences in the composition and structure of histological elements formed from cambium at different times of the year (Figure 4).

By the number of tree rings, you can determine the age of the plant. The secondary xylem, which occupies most of the section, is easy to determine, since its cells are stained red-brown. It is represented by tracheid located in radial rows and sparse, elongated and short core rays. The core is not wide, it is represented by large and small round-oval, thin-walled parenchymal cells and they contain hydrocytic cells (Figure 4).

The root is the axial organ of the plant, which has radial symmetry, has unlimited long growth, has root hairs and a cap and does not form any other organs on itself. The main functions of the root are the absorption of water and minerals dissolved in it from the soil, the attachment of the plant organism to the substrate and the synthesis of organic substances (amino acids, nucleotides, hormones, enzymes and alkaloids).

In addition, it performs other functions: supply of nutrients, respiration, vegetative propagation, communication with soil microorganisms. The base of the root on the cross section is round, bundled, more lignified. In the anatomical structure of the roots of the studied species, three main zones can be distinguished: the periderm, secondary cortex, and central cylinder.

The primary crust with a secondary thickening of the root, as a rule, breaks and dies. The integumentary tissue is a cork; at large roots, the cork replaces the cork. Perennial root with a multilayer crust, including large numerous groups of bast fibers and periderm (Figure 5).

The periderm is three-layered, consists of a phellogen, a phellem and a phelloderm. Phellogen cells are rectangular flattened in the radial direction and passing from the outside to the phellem cells, inside-the cells of the phelloderm cell are clearly distinguished from the cells of the inner cortex by a larger size and rectangular flattened in the radial direction. Under the periderm is a round-oval secondary cortical parenchyma, which consists of 6 - 7 rows and remains throughout (Figure 5). 


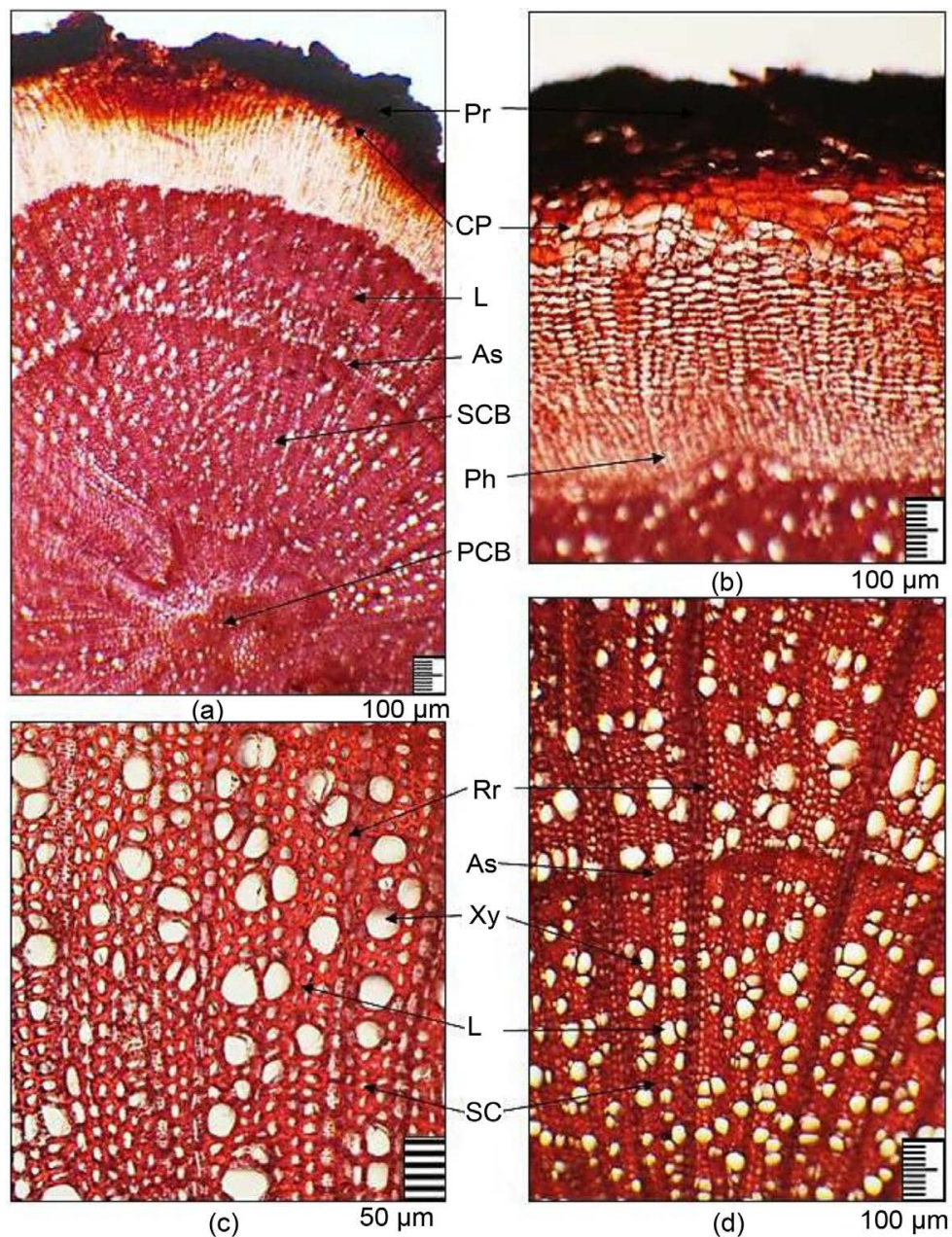

Figure 5. Anatomical structure of the root of Lavandula officinalis in the cross section: (a) general view of the root; (b) cortex parenchyma and phloem; (c)-(d) secondary conductive bundles and radial rays. Legend: As-annual shoot, $\mathrm{CP}$-cortex parenchyma, L-libriform, $\mathrm{PCB}$ - primary conductive bundles, $\mathrm{Ph}$-phloem, $\mathrm{Pr}$-periderm, $\mathrm{Px}$-parenchyma, $\mathrm{Rr}$-radial rays, $\mathrm{SC}$-sclerenchyma, $\mathrm{SCB}$ - secondary conductive bundles, Xy-xylem. Magnification-50 - 100 micron.

Under the cortex parenchyma groups of bast fibers are formed. The phloem is extensive, located between the cortex parenchyma and libriform. Wood occupies a continuous central root cylinder. Primary conductive tissues are preserved in the root, and then secondary ones immediately form a continuous cylinder, which in the cross section has the form of solid ring. Secondary xylem, occupying most of the slice. The vessels in the secondary xylem are larger, with thickened walls. It is represented by tracheid located in radial rows and radial rays. Radial rays are 1 - 3 rows, their cells are elongated, filled with tannins (Figure 5).

Thus, for the first time under the introduction of the Tashkent Botanical Garden (Uzbekistan), an anatomical and histological study of the autonomic organs of Lavandula officinalis was carried out. The results obtained made it possible to determine a number of morphological, anatomical, and histological 
and characteristic diagnostic characters for this species. Our studies have shown that the presence or absence of trichomes can serve as an informative sign. In $L$. officinalis, trichomes are simple, single-cell, double-ended; three-pointed; multi-end. Lavender leaf hairs that accumulate essential oils under the cuticle of secreting cells, the cuticle are tightly attached to the membranes of the secretory cells due to the absence of secretion products. When treated with a solution of methylene blue and safranin, drops of yellow-orange essential oil are found in the epidermal, palisade and bark parenchymal cells. Identified diagnostic features that can be used in taxonomy and can be used to identify plant materials can also be used to develop indicators of authenticity in this type of raw material.

\section{Conflicts of Interest}

The authors declare no conflicts of interest regarding the publication of this paper.

\section{References}

[1] Linnaei, C. (1753) Species Plantirum, Exhibentes plantas rite cognitas, ag genera relatas cum differentis specificis, nominibus trivialibus, synonymis selectus, locis natalibus. Holmiae, 2, 572-573. https://doi.org/10.5962/bhl.title.669

[2] Zatuchny, V.L. and Kigelman, M.Kh. (1972) Biology and Features of Agricultural Technology of Lavender in the USSR. Essential Oil Crops of Moldova and Essential Oils: Collection. In: Scientific TR, Publishing House of the Central Committee of the Communist Party of Moldova, Chisinau, 24-39. (In Russian)

[3] Leshchuk, T.Ya. (1952) Lavender Is Real. Essential Oil Plants of the South of the USSR. Krimizdat, Simferopol, 48-68. (In Russian)

[4] Leshchuk, T.Ya. and Mashanov, V.I. (1960) For High Yields of Lavender. Krimizdat, Simferopol, 77. (In Russian)

[5] Luzina, L.V. (1968) Lavender Selection. In: Sat. Essential Oil Raw Materials and Technology of Essential Oils, Publishing House of Food Industry, Moscow, 72-81. (In Russian)

[6] Mashanov, V.I., Kalchenko, A.K. and Leshchuk, T.Ya. (1972) Biological Principles of Lavender Cultivation. Tavria, Simferopol, 125. (In Russian)

[7] GRIN (2010) Species Records of Lavandula [Germplasm Resources Information Network (GRIN)]. [Electronic Resource]. National Germplasm Resources Laboratory, Beltsville.

[8] Upson, T.M. and Andrews, S. (2004) The Genus Lavandula. A Botanical Magazine Monograph. Royal Botanic Gardens, Kew, 442.

[9] Urwin, N. (2009) Improvement of Lavender Varieties by Manipulation of Chromosome Number. RIRDC (Rural Industries Research and Development Corporation, Australia), Charles Sturt University, Canberra, 30 p.

[10] Zobenko, L.P., Romanenko, L.G. and Karpacheva, A.N. (1975) Comparative Study of the Clonal and Seed Methods of Propagation of Real Lavender: Tr. VNIIEMK. Simferopol, 8, 29-32. (In Russian)

[11] Gorbunova, E.O. (1996) Biological Features of Lavender Narrow-Leaved Introduction in the Moscow Region Author's Abstract of Dissertation Candidate of Biologi- 
cal Sciences, Moscow, 20. (In Russian)

[12] https://ru.wikipedia.org/wiki

[13] Romanenko, L.G. (1977) Lavender: Sat: Selection of Essential Oil Crops. VNIIEMK, Simferopol, 47-66. (In Russian)

[14] Voronina, E.P., Gorbunov, Yu.N. and Gorbunova, Ye.O. (2001) New Aromatic Plants for the Non-Black Earth Region. Nauka, Moscow, 173. (In Russian)

[15] Bostanova, L.X. (2006) Endo- and Exogenous Antibacterial Activity of Lavender Callus (Lavandula angustifolia Mill.). Promising Areas of Physico-Chemical Biology and Biotechnology: Abstracts and Posters of the XVIII Winter Youth Scientific School, Moscow, 89. (In Russian)

[16] Blinova, K.F. and Yakovlev, G.P. (1990) Botanical and Pharmacognostic Dictionary: Ref. Allowance. Higher School, Moscow, 202. (In Russian)

[17] Duschanova, G.M. (2016) Adaptive Features of Vegetative Organs of Species of the Genus Climacoptera Botsch. Thesis of Doctor of Biological Sciences, Tashkent, 35-36. (In Russian)

[18] Dusmuratova, F.M. (2011) Bioecological Features of Atropa belladonna L. under Conditions of Introduction (Botanical Garden, Tashkent) Abstract of Dissertation Candidate of Biological Sciences, Tashkent, 23. (In Russian)

[19] Barykina, R.P., Veselova, T.D., Devyatov, A.G., et al. (2004) Handbook of Botanical Microtechnology (Basics and Methods). Publishing House Moscow State University, Moscow, 6-68.

[20] Esau, K. (1969) Anatomy of Plants. Publishing House World, Moscow, 138-416.

[21] Kiseleva, N.S. (1971) Anatomy and Morphology of Plants. Publ. Higher School, Minsk, 89-119, 215-227.

[22] Zakharevich, S.F. (1954) On the Methodology for Describing the Epidermis of the Leaf. Vestnik LSU. Leningrad, 4, 65-75. 